\title{
Cervical Cancer Awareness: An Information Dissemination Campaign In Indonesia
}

\author{
Dedeh Sri Rahayu ${ }^{1}$, Marcos Ochoa ${ }^{2}$ \\ ${ }^{1}$ STIKes Budi Luhur, ${ }^{2}$ Phipippine Women's University \\ E-mail:defizi2011@gmail.com
}

\begin{abstract}
This descriptive-correlational study was conducted to determine the level of cervical cancer awareness of 196 participants who were conveniently recruited from selected regions in South Cimahi, Melong, West Java, Indonesia. The survey was conducted on February 2014 for fifteen (15) days using a survey questionnaire for data collection. Descriptive statistics such as frequency and percentage distribution were used for demographic profile and weighted mean for the assessment of the level of awareness on cervical cancer, and inferential statistics such as Pearson $r$ and chi square for hypothesis testing. They have moderate awareness on basic information on cervical cancer, foremost are the areas on prevention, anatomy, treatment and common diagnostic examination, but with very little knowledge or partial awareness on the items pertaining to signs and symptoms, etiology and mode of transmission of cervical cancer. The results of chi square and pearson $r$ tests found that the participants' gender and educational attainment were not significantly correlated with their level of awareness on cervical cancer while, family monthly income was significantly correlated to their level of awareness. Hence, this study concluded that gender and educational attainment do not necessarily determine a person's level of awareness or knowledge but family income could contribute to their level of awareness. The study findings formed the basis of designing an information dissemination campaign material on cervical cancer among the residents of South Cimahi, Indonesia. In this regard, an intensive information dissemination campaign program on cervical cancer is recommended using the proposed campaign material designed.
\end{abstract}

Kata kunci: Campaign, cervical cancer, detection, dissemination.

\section{Kampanye di Indonesia: Deteksi Dini Kanker Serviks}

\begin{abstract}
Abstrak
Penelitian deskriptif-korelasional ini dilakukan untuk mengetahui tingkat kesadaran 196 peserta yang nyaman direkrut dari daerah tertentu di Cimahi Selatan, Melong, Jawa Barat, Indonesia. Pengumpulan data menggunakan kuesioner. Statistik deskriptif digunakan untuk profil demografis dan rata-rata untuk penilaian tingkat kesadaran mengenai kanker serviks, dan statistik inferensi seperti Pearson $r$ dan Chi square untuk pengujian hipotesis. Hasil penelitian menunjukkan bahwa responden memiliki kesadaran moderat pada informasi dasar tentang kanker serviks, terutama adalah daerah tentang pencegahan, anatomi, pengobatan dan pemeriksaan diagnostik umum, tetapi dengan sedikit pengetahuan atau kesadaran parsial pada item yang berkaitan dengan tandatanda dan gejala, etiologi dan cara penularan kanker serviks. Kemudian ditunjukkan bahwa gender dan pendidikan pencapaian peserta tidak signifikan berkorelasi dengan tingkat kesadaran pada saat kanker serviks, pendapatan bulanan keluarga secara signifikan berhubungan dengan tingkat kesadaran. Penelitian ini menyimpulkan bahwa gender dan pencapaian pendidikan tidak selalu menentukan tingkat kesadaran seseorang atau pengetahuan tetapi pendapatan keluarga dapat memberikan kontribusi untuk tingkat kesadaran.
\end{abstract}

Key words: Deteksi, disseminasi, kampanye, kanker serviks. 
Dedeh Sri Rahayu: Cervical Cancer Awareness: An Information Dissemination Campaign Indonesia

\section{Background}

Cervical cancer is one of the leading health problems striking women worldwide with an estimated 529,409 new cases and approximately eighty six percent (86\%) in developing countries, WHO (2011). Due to household chores and number of children in their family being taken cared of women's, tend to neglect their health status. They only visit health centers when something is wrong with their health condition. This scenario is true especially in developing countries including Indonesia. Despite the accessibility, affordability, and availability of health services in the community, most married women could not afford to take advantage of it because of several factors such as ignorance to health risks and the old practices than they inherited from the old generation in terms of treating illnesses and lack of knowledge related to women's health.

Itoh Tochija (2012) mentioned that most women in Indonesia suffer from cancer due to lack of knowledge. To overcome this, the Indonesian Cancer Foundation, Cimahi branch, cooperated with the government to give health education for women on Melong. In coping and developing cervical cancer awareness, the community health center in Melong established women's services. The programs include counseling, cervical cancer screening and other human health services were initiated since March, 2012. However, some health of these services can not be implemented because of religious constraints. Reluctance among women for physical examination is very high due to conservative practices. Uncovering the private parts for medical check-ups namely check Pap smear is one of the obstacles such because they feel shame. Women tend to get medical help when their condition is already severe.

Cancer among women Indonesia progressed rapidly every year. In 2009; cancer in women case were recorded at 250 where $18.93 \%$ was breast cancer and $15.38 \%$ cervical cancer. In 2010, cancer case were recorded at 260 and in 2011, cancer case were recorded at 233 where breast cancer is at $22.23 \%$ and $13.73 \%$ cervical cancer (Cimahi Health Service ,2012).

The researcher pursues this study in order to determine the level of awareness among men, women in selected regions in South Cimahi, Melong, Indonesia on cervical cancer and be able to design cervical cancer awareness dissemination campaign material.

This study aimed to determine the level of awareness of participants on cervical cancer in selected villages within West Java, Cimahi as basis for a proposed information dissemination campaign material.

Specifically, the study sought answers to the following questions :

1. What is the demographic profile of the participants in terms of :

1.1 gender;

1.2 educational attainment; and

1.3 family monthly income?

2. What is the participants's level of awareness on cervical cancer?

3. Is there a significant relationship between the demographic profile of the participants and their level of awareness on cervical cancer?

4. Based on the findings of the study, what information dissemination campaign material can be designed ?

The hypothesis below was tested at 0.05 level of significance: There is no significant relationship between the demographic profile of the participants and their level of awareness on cervical cancer.

This study was focused on determining the level of awareness of participants on cervical cancer in selected regions in South Cimahi, Melong, Indonesia. The participants were ninety eight (98) couples, for a total of one hundred ninety six (196). The survey was conducted on February 2014 for fifteen (15) days using a researcher- made questionnaire for data collection. Descriptive statistics such as frequency and percentage distribution were used for demographic profile and weighted mean for the assessment of the level of awareness on cervical cancer, and inferential statistics such as Pearson $r$ and Chi square for hypothesis testing.

\section{Method}

The study made use of descriptivecorrelational design. Descriptive survey research is used to describe characteristics, 
Dedeh Sri Rahayu: Cervical Cancer Awareness: An Information Dissemination Campaign Indonesia

INPUT

1. Demographic
Profile:
a. Gender
b. Educational
attainment
c. Family
monthly
income

2. Cervical cancer

Awareness

3. Pender's Promotion Health Theory
PROCESS

\begin{tabular}{|l|}
\hline \\
$\checkmark$ Contruction and \\
Validation of \\
Questionnaire \\
$\checkmark$ Administration of \\
questionnaire \\
$\checkmark$ Statistical treatment \\
of data \\
$\checkmark$ Designing of \\
information \\
dessimination \\
campaign material
\end{tabular}

OUTPUT

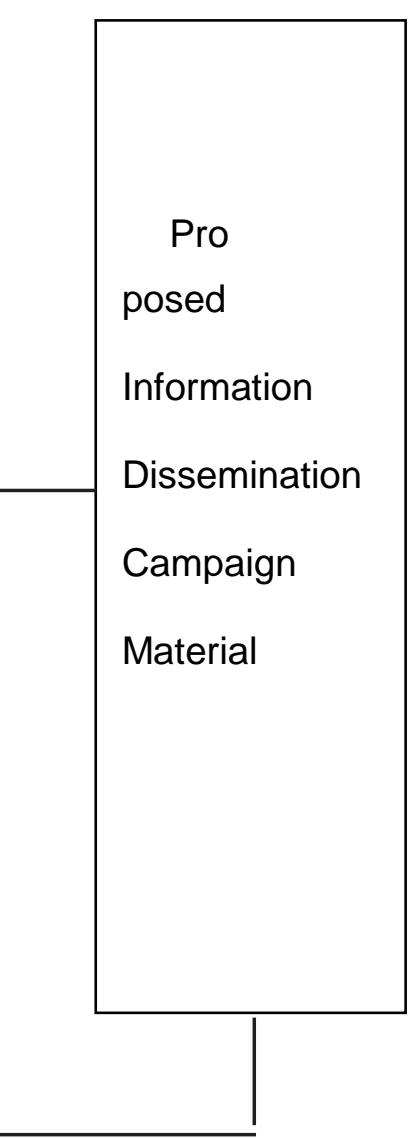

opinions and attitudes or behaviors as they currently exist in a target population (Keele, 2010 cited in Valdez, 2013).

The correlation design was used to examine the relationships between demographic profile variables and level of awareness on cervical cancer of participants in selected villages in Melong, Cimahi, Indonesia. Construction. The main tool for data collection was a survey questionnaire, developed by the researcher based on the various related literature and similar studies on cervical cancer.

The questionnaire was pilot tested to fifteen (15) residents of Melong who were not part of the study for further validation. The questions used in this study were reliable according to the result of the analysis using Pearson $r$. The obtained value of Alpha Cronbach is $0.989>$ r 0.6 is constant making the questions used in this study as reliable.

A formal written permission was obtained from the head of the Unity of the Nation and to the head of Cimahi Health Department,
West Java Indonesia. The researcher has received and granted permission from both institutions coursed through Melong's Public Health Center, to distribute questionnaires to the regions as mentioned in the letter.

Table 1 shows the demographic profile of the participants such as gender, educational level and family monthly income.

In this study, male and female genders were equally represented, at 50\% each. Men were included in this study to get them involved in the prevention of cervical cancer. This is supported by the study of Meutia (2014), although cervical cancer occurs only in women, men's behavior is instrumental in its spread.

In terms of educational attainment, data showed that majority (51 \%) of them had reached junior high school, followed by senior high school graduates with 33\% and only $1 \%$ reached university level. This finding may indicate that the participants were not interested in obtaining higher educational 
Dedeh Sri Rahayu: Cervical Cancer Awareness: An Information Dissemination Campaign Indonesia

Table 1 Distribution of Demografic Profile

\begin{tabular}{lcc}
\hline \multicolumn{1}{c}{ Variables } & Frequency (f) & Percentage (\%) \\
\hline a. Gender & 98 & 50.00 \\
Female & 98 & 50.00 \\
Male & 196 & 100.00 \\
Total & & \\
b. Educational Attainment & 29 & 15.00 \\
Primary School & 100 & 51.00 \\
Junior High School & 65 & 33.00 \\
Senior High School & 2 & 1.00 \\
University & 196 & 100.00 \\
Total & & \\
c. Family Monthly Income (in & & \\
Rupiah) & 54 & 53.00 \\
$500.000-1,500.000$ & 35 & 34.00 \\
1,501.000- 2,500.000 & 12 & 12.00 \\
2,501.000 - 3,500.000 & 1 & 1.00 \\
3,501.000 - 4,500.000 & 98 & 100.00 \\
Total & & \\
\hline
\end{tabular}

attainment. The low level of education could affect the level of their awareness on cervical cancer. Peckenpaugh (2009) pointed out that the increase in cases of cancer is related to educational, demographic changes and psychosocial factors. Likewise, women with more education demonstrate greater knowledge (Xu, Zhang, $\mathrm{Wu}$ and Zhang , 2011).

In terms of family monthly income, $54 \%$ of the couples' income ranged from R500,000-1,500,000 rupiah (Php 1,852.00 to Php 5,555.00) while as only $1 \%$ of had a combined monthly income of R3,501.000 (Php 12,964.00).
This study findings found that most of the participants belonged to the low-income stratum. The data could be attributed to the participants' low educational attainment which could result to low paying jobs. Low socio-economic status is a factor in the occurrence of cervical cancer (Ricci \& Kyle, 2009) and socioeconomic level affects an individual's ability to pay health care activities and health promotion. Often, limited funds and resources available to access needed services. People may delay seeking treatment or information due to a lack of money (Maville, 2013).

Table 2 Level Awareness on Cervical Cancer

\begin{tabular}{lcc}
\hline \multicolumn{1}{c}{ Indicators } & Mean Level & Descriptive index \\
\hline Do you know that..... & & \\
A. Anatomy & 1.78 & Moderately aware \\
1. the cervix is in female reproductive system & 1.61 & Moderately aware \\
2. the cervix is cylinder-shaped neck tissue that connects \\
the uterus and the vagina \\
$\begin{array}{l}\text { Sub mean } \\
\text { B. Etiology/Risk factor }\end{array}$ \\
\begin{tabular}{l} 
3. cervical ca ncer is a cancer of uterine cervix \\
\hline
\end{tabular}
\end{tabular}


Dedeh Sri Rahayu: Cervical Cancer Awareness: An Information Dissemination Campaign Indonesia

\begin{tabular}{|c|c|c|}
\hline Indicators & Mean Level & Descriptive index \\
\hline 4. cervical cancer is caused by human papillomavirus & 1.85 & Moderately aware \\
\hline $\begin{array}{l}\text { 5. Having sex at a young age is a risk factor for cervical } \\
\text { cancer }\end{array}$ & 1.66 & Moderately aware \\
\hline $\begin{array}{l}\text { 6. the risk of cervical cancer is cause by multiple sex } \\
\text { partners }\end{array}$ & 1.60 & Moderately aware \\
\hline $\begin{array}{l}\text { 7. one of the cause of cervical cancer is long time use of } \\
\text { contraceptives pill }\end{array}$ & 1.45 & Partly aware \\
\hline $\begin{array}{l}\text { 8. cervical cancer may occur due to some genetic factors } \\
\text { from the parents }\end{array}$ & 0.92 & Partly aware \\
\hline $\begin{array}{l}\text { 9. women with poor vaginal hygiene are at risk of cervical } \\
\text { cancer }\end{array}$ & 1.07 & Partly aware \\
\hline $\begin{array}{l}\text { 10. one of the cause of cervical cancer may occur from } \\
\text { husband who are not circumcised and with poor penile } \\
\text { hygiene }\end{array}$ & 1.29 & Partly aware \\
\hline Sub mean & 1.46 & Partly aware \\
\hline \multicolumn{3}{|l|}{ C. Mode of transmition } \\
\hline $\begin{array}{l}\text { 11. cervical cancer can be transmitted through sexual } \\
\text { contact? }\end{array}$ & 1.20 & Partly aware \\
\hline $\begin{array}{l}\text { 12. transmission of cervical cancer is through multiple } \\
\text { sexual intercourse? }\end{array}$ & 1.47 & Partly aware \\
\hline Sub mean & 1.34 & Partly aware \\
\hline \multicolumn{3}{|l|}{ D. Sign and Symptom } \\
\hline 13. One of the sign of cervical cancer is bleeding & 1.22 & Partly aware \\
\hline $\begin{array}{l}\text { 14. vaginal discharge with foul smell odor and difficulty } \\
\text { in urinating is olso sign of cervical cancer }\end{array}$ & 1.30 & Partly aware \\
\hline $\begin{array}{l}\text { 15. the symptoms of cervical cancer is pain in the lower } \\
\text { abdomen and vagina itching }\end{array}$ & 1.35 & Partly aware \\
\hline $\begin{array}{l}\text { 16. the symptoms of cervical cancer are pelvic pain, and it } \\
\text { may radiate to the feet }\end{array}$ & 0.98 & Partly aware \\
\hline Sub mean & 1.21 & Partly aware \\
\hline $\begin{array}{l}\text { 17. an early prevention of getting cervical cancer is by } \\
\text { examination of the visual inspection of acetic acid }\end{array}$ & 1.09 & Partly aware \\
\hline $\begin{array}{l}\text { 18. an early prevention of getting cervical cancer is true } \\
\text { pap smear examination }\end{array}$ & 1.47 & Partly aware \\
\hline $\begin{array}{l}\text { 19. pap smears and direct inspection with acetic acid is } \\
\text { done immediately after having sex }\end{array}$ & 1.72 & Moderately aware \\
\hline $\begin{array}{l}\text { 20. pap smears and direct inspection with acetic acid } \\
\text { carried out every 2-3 years }\end{array}$ & 1.71 & Moderately aware \\
\hline $\begin{array}{l}\text { 21. pap smear and visual is done to collect cervical mucus } \\
\text { inspection with acetic acid that is for examination in } \\
\text { laboratory }\end{array}$ & 1.39 & partly aware \\
\hline $\begin{array}{l}\text { 22. cervical biopsy:is taking tissue samples from the } \\
\text { cervix to check for cervical cancer }\end{array}$ & 1.58 & Moderately aware \\
\hline $\begin{array}{l}\text { 23. colposcopy is follow-up test for Pap smear test using } \\
\text { magnifying glass, to detect abnormal cell }\end{array}$ & 1.59 & Moderately aware \\
\hline Sub mean & 1.51 & Moderately aware \\
\hline
\end{tabular}


Dedeh Sri Rahayu: Cervical Cancer Awareness: An Information Dissemination Campaign Indonesia

\begin{tabular}{|c|c|c|}
\hline Indicators & Mean Level & Descriptive index \\
\hline \multicolumn{3}{|l|}{ F. Prevention } \\
\hline $\begin{array}{l}\text { 24. the prevention of cervical cancer could be done } \\
\text { by injecting the Gardasil vaccine, cervarix or other } \\
\text { brand, of vaccine with physicians order }\end{array}$ & 1.69 & Moderately aware \\
\hline $\begin{array}{l}\text { 25. Broccoli / cabbage, carrot, garlic, onion, turmeric, } \\
\text { soy, green tea, tomatoes contain anti-oxidants that are } \\
\text { able to prevent cervical cancer }\end{array}$ & 1.76 & Moderately aware \\
\hline $\begin{array}{l}\text { 26. citrus, avocado, berry, blueberry, strawberry } \\
\text { and chocolate contains anti-oxidants that are able to } \\
\text { prevent cervical cancer }\end{array}$ & 1.69 & Moderately aware \\
\hline $\begin{array}{l}\text { 27. eating nutritious food will increase endurance and } \\
\text { can prevent the HPV virus }\end{array}$ & 1.79 & Moderately aware \\
\hline $\begin{array}{l}\text { 28. vitamin E in olive oil, safflower oil, sunflower oil, } \\
\text { nuts, almonds, whole wheat bread, and whole grain } \\
\text { cereals may prevent cancer }\end{array}$ & 1.71 & Moderately aware \\
\hline $\begin{array}{l}\text { 29. women who have never experienced health } \\
\text { check-ups in the reproductive system may be at risk } \\
\text { of cervical cancer }\end{array}$ & 1.64 & Moderately aware \\
\hline Sub mean & 1.71 & Moderately aware \\
\hline \multicolumn{3}{|l|}{ G. Treatment } \\
\hline $\begin{array}{l}\text { 30. antibiotics: kill and prevent multiplication of } \\
\text { abnormal cells that cause cervical cancer }\end{array}$ & 1.68 & Moderately aware \\
\hline $\begin{array}{l}\text { 31. cryo: freezing aims to kill the abnormal cells, to } \\
\text { prevents cervical cancer }\end{array}$ & 1.53 & Moderately aware \\
\hline $\begin{array}{l}\text { 32. chemotherapy: is the most common treatment for } \\
\text { cervical cancer in the hospital }\end{array}$ & 1.78 & Moderately aware \\
\hline $\begin{array}{l}\text { 33. Surgical removal of the uterus and cervix is done } \\
\text { to prevent spead of cancer cell in the body }\end{array}$ & 1.45 & Partly aware \\
\hline Sub mean & 1.61 & Moderately aware \\
\hline Grand mean & 1.51 & Moderately aware \\
\hline \multicolumn{3}{|l|}{ Legend: } \\
\hline \multicolumn{3}{|l|}{2.26 - 3.00 Very Much Aware } \\
\hline \multicolumn{3}{|l|}{ 1.51- 2.25 Moderately Aware } \\
\hline \multicolumn{3}{|l|}{$0.76-1.50$ Partly Aware } \\
\hline $0.01-0.75$ Unaware & & \\
\hline
\end{tabular}

The data revealed that couples have fundamental knowledge on the different areas about cervical cancer on the average. The highest rating was reflected on the area of prevention $(\mathrm{SM}=1.71)$. The ratings for all the indicators in this area ranged from 1.64 to 1.79 indicated that they possessed an average knowledge on prevention of cervical cancer. Likewise, the ratings on the areas of anatomy and treatment reflected almost similar level of awareness, which was moderate or have knowledge on the average. The could mean that the knowledge they acquired on the prevention of cervical cancer and the reproductive system's anatomy as well as ways of treatment were learned from school and from other literatures such as a magazines and other reading materials. According to the Cancer Foundation of Indonesia (2011), information about cervical cancer were contained in leaflets, flip books, slides and basic information from lectures on radio, television, print media and seminars.

On the other hand, the areas on signs and symptoms, etiology and mode of transmission obtained the lowest mean ratings 121, 134 
Dedeh Sri Rahayu: Cervical Cancer Awareness: An Information Dissemination Campaign Indonesia

and 1.46 respectively. These indicated that the participants were only partly aware of most of the indicators. This means that they have very little knowledge about the cervical cancer's signs and symptoms, etiology and mode of transmission.

In the area of signs and symptoms, the item with the lowest mean score of 0.98 is "the symptoms of cervical cancer are pelvic pain, and it may radiate to the feet”. This revealed that the couples have very little knowledge on this specific symptom. This may be attributed to the fact that all the spouses of the male participants do not have cervical cancer and that they were never exposed to any known person with cervical cancer. Likewise, this symptom is manifested in women with advanced cervical cancer.

The item on the area of mode of transmission that got the lowest mean of 1.20 was on "cervical cancer can be transmitted through sexual contact". This finding revealed that they have very little knowledge that cervical cancer can be transmitted through multiple sex partners. Multiple sex partners in the Muslim culture is a taboo because they firmly believed that sexual relationship outside marriage is unlawful.

Lastly, the item on the area of etiology that got the lowest rating of 0.92 is,

" cervical cancer may occur due to some genetic factors from the parents". The participants have not known that genes are considered as a one of the predisposing factor in the development of cervical cancer. This information that can only be known to those who have cervical cancer; as this information can be learned from their physicians. .

Table 3 presents the summary of level of awareness of participants on cervical cancer. The three areas where the participants displayed moderate awareness, obtaining the highest mean ratings are prevention (1.71), and anatomy (1.70) and treatment (1.61). On the other hand, the participants showed very little knowledge on the areas of signs and symptoms (1.21), and mode of transmission (1.34).

Overall, it is noted that most of the participants possessed moderate awareness or average knowledge on the basic information about cervical knowledge in most areas having obtained a grand mean of 1.51 . However, the data in the areas of signs and

Table 3 Summary of Level of Awareness on Cervical Cancer

\begin{tabular}{lccc}
\hline \multicolumn{1}{c}{ Indicators } & Sub mean & Description & Rank \\
\hline A. Anatomy & 1.70 & MA & 2 \\
B. Etiology & 1.46 & MA & 4 \\
C. Mode of Transmission & 1.34 & PA & 5 \\
D. Signs and Symptoms & 1.21 & PA & 6 \\
E. Diagnostic Examination & 1.51 & MA & 4 \\
F. Prevention & 1.71 & MA & 1 \\
G. Treatment & 1.61 & MA & 3 \\
Grand Mean & 1.51 & MA & \\
\hline
\end{tabular}

\begin{tabular}{lcccccc}
\hline \multicolumn{1}{c}{ Variables } & Df & $\begin{array}{c}\text { Critical } \\
\text { X2 Value } \\
(\boldsymbol{\alpha}=\mathbf{. 0 5})\end{array}$ & $\begin{array}{c}\text { Computed } \\
\text { X2 Value }\end{array}$ & Interpretation & Decision \\
\hline $\begin{array}{l}\text { 1. Gender and level of } \\
\text { awareness }\end{array}$ & 3 & 7.815 & .373 & Not Significant & Accept Ho \\
$\begin{array}{l}\text { 2.Educational Attainment and } \\
\text { level of awareness }\end{array}$ & 9 & 16.919 & 14.804 & Not significant & Accept Ho \\
$\begin{array}{l}\text { 3.Family monthly income and } \\
\text { level of awareness }\end{array}$ & 194 & $\begin{array}{c}\text { Critical rxy } \\
\text { Value }(\alpha=.05) \\
\mathbf{0 7 3}\end{array}$ & $\begin{array}{c}\text { Computed rxy } \\
\text { Value } \\
\mathbf{. 1 9 4}\end{array}$ & Significant & Reject Ho \\
\hline
\end{tabular}


Dedeh Sri Rahayu: Cervical Cancer Awareness: An Information Dissemination Campaign Indonesia

symptoms and etiology, which obtained the two lowest rating, signified that they have little or were only partly aware about the signs and symptoms and etiology of cervical cancer. The knowledge that supports disease prevention and raising awareness on cervical cancer is the goal of health promotion.

Table 4 shows the results on the significant relationship between the participants' selected profile variables and their level of awareness on cervical cancer. Pearson $r$ and chi square were used to test if there is a correlative significance between gender, educational attainment and family monthly income to the participants' level of awareness on cervical cancer.

The result of Chi square test to measure the significant relationship between gender and level of cervical cancer awareness showed the alpha level 0.05 with $\mathrm{df}$ of 3 ; the critical value of 7.815 is greater than the computed $t$ of 0.373 , interpreted as not significant.

Likewise, the results of chi square test between educational level and the level of awareness at alpha level 0.05 with df of 9, the critical value of 16.919 , is greater than computed $t$ value 14.804, interpreted as not significant. Therefore the null hypothesis on these variables is accepted.

The findings revealed that genders as well as educational level of the participants and their level of awareness are not significantly correlated. This means that gender and educational attainment do not determine a person's knowledge or awareness on cervical cancer. With regards to gender, this study finding is contrary to the study findings of Ruth, Ekowati, and Kristanto (2013), that men's awareness about cervical cancer is lower than adult women. Hawks (2009) cited in Maville (2013), further emphasized that men's awareness about cervical cancer is lower compared to women because women avail of the health care system more often than men because of the nature of women as reproductive and child rearing.

As for the participants' educational attainment, it is noteworthy that although most of the participants only reached junior high school, they were able to acquire an average knowledge or moderate level of awareness on cervical cancer. Highly educated individuals are not necessarily knowledgeable on cervical cancer compared to those with lower education.

Pearson $r$ test was done to test the significant relationship between family monthly income and level of cervical cancer awareness. Alpha level 0.05 and .194 degrees of freedom were used, with critical value of .073 , which is less than the computed value of 194, showed that there is a significant relationship between family income and level of awareness. Therefore, the null hypothesis is rejected.

This means that family monthly income may affect the level of awareness or knowledge of participants on cervical cancer. The low monthly income of the participants could have contributed to their moderate level of awareness on most of the indicators and very little knowledge on etiology and signs and symptoms of cervical cancer. In contrast, the study findings of De Guzman (2012), showed that the monthly income have little effect on the awareness of cervical cancer .

\section{Summary}

1. Demographic Profile of Participants

In this study, both male and female participants were equally represented at 50\% each; majority of them or $51 \%$ had reached junior high school and mostly belonged to the lowincome bracket with only about R500,000 to $\mathrm{R} 1,500,000$ or roughly about Php $1,852.00$ to Php 5,556.00 combined family income.

\section{Level of Awareness level on Cervical Cancer}

The participants of this study have obtained an over- all mean of 1.51 , which is described as "moderately aware". They have an average knowledge or moderate awareness on basic information on cervical cancer

3. Significant Relationship Between Demographic Profile and Level of Awareness on Cervical Cancer

The results of Chi square and pearson $r$ tests revealed that the participants' gender and educational attainment were not significantly correlated with their level of awareness on cervical cancer. Both men and women and those with high school diploma and college degree have the same moderate 
Dedeh Sri Rahayu: Cervical Cancer Awareness: An Information Dissemination Campaign Indonesia

level of awareness on cervical cancer. On the other hand, family monthly income was significantly correlated to the participants' level of awareness.

\section{Conclusions}

Based on the findings of this study, the following conclusions are drawn :

1. Gender and educational attainment do not necessarily determine a person's level of awareness or knowledge.

2. Family income contributes to the participants' acquisition of knowledge on cervical cancer.

3 . Since gender and educational attainment have no significant relationship with participants' level of awareness, thus, the null hypothesis is accepted. But the null hypothesis with regards to family monthly income, which showed significant relationship to level of awareness, is rejected. 4. The dissemination of information use the model promoting the health Pender (1996 ) in Maville and Huerta ( 2013 ), focused on activities that may increase public welfare and prevent the occurrence of an outbreak of the disease.

5. This kind of matter a comic campaign to strengthen the level of awareness about cervical cancer in Melong, can be given to citizens by health workers and students the community health such as students midwifery and nursing during its outreach activities on the community .

\section{Recommendations}

Based on the findings and conclusions of this study, the following are recommended :

1. The health centres in the various villages on Melong, in coordination with the Health Department should spearhead programs and activities that would help improve the people's awareness on cervical cancer. These could include short adult health education classes, home visitations by public health officers and small group discussions.

2. An information dissemination campaign program on cervical cancer should be conducted by the government clinics using the proposed campaign material designed based on the findings of this study. The comictype campaign material can be given out to the residents by public health personnel and allied health students such as midwifery and nursing students during community outreach activities.

3. Intensive public cervical cancer detection examinations should be initiated by the local government utilizing public health centers and be made available to all female residents of Melong, Indonesia.

4. For further studies, it is recommended that similar topics, such as :

4.1 follow up study utilizing the same research locales to determine whether the level of public awareness relative to cervical cancer has significanly improved; and

4.2. qualitative researches like case study or ethno- phenomological study focusing on the norms and traditions of the existing culture of Muslim women.

\section{References}

Aditya, E. P, (2013). Pria tidak disunat bisa membuat pasangannya menderita kanker rahim. Diunduh dari http://liputan6.com pada November. 2013.

American Cancer Society, (2009). Cancer facts and figures. Diunduh dari http://www. cancer.org/downloads pada 16 Oktober, 2013.

American Institute for Cancer Research, (2009). Food, nutrition, and the prevention of cancer: A Global Perspective. Washington, DC: Author. Diunduh pada 16 Oktober, 2013.

Andriani, E. (2010). Kanker serviks. Diunduh dari http://eviandrianimosy.blogspot. com/2010/06/kanker serviks-cervical.html pada 18 Oktober 2013.

Arumaniez, (2010). Human Papilloma Virus (HPV) penyebab kanker serviks. Diunduh dari http://arumaniez21.wordpress. com/2010/02/21/hpv-penyebab-kankerserviks/ pada 18 October 2013.

Brankovic, I. (2013), Applying a gender lens on Human Papilloma Virus infection: Cervical 
Dedeh Sri Rahayu: Cervical Cancer Awareness: An Information Dissemination Campaign Indonesia

cancer screening, HPV DNA testing, and HPV vaccination. Intenational Journal for Equity in Health, 12, 14. doi:10.1186/14759276-12-14.

Department of Health. (2009). NHS Cervical Screening Annual Review 2009 . Diunduh dari www.cancerscreening.nhs.uk/cervícal/ publícations/cervicaí-annuaíreview-2009. pdf.

Departemen Pendidikan dan Kebudayaan. (2009). Kamus besar bahasa Indonesia. Jakarta: Balai Pustaka.

Dib, R. (2013). Self-awareness. Diunduh dari http://www.answer.com/topic/ awareness\#Selfawareness pada November 2013.

Dolara, P. (2012), Antioxidant vitamins and mineral supplementation, life span expansion and cancer incidence: Acritical commentary. Eur J Nutr, 51, 769-781. doi: 10.1007/s00394012-0389-2. Diunduh pada 16 Oktober 2013.

Edward, B. R. (2009) Medical dictionary and health guide. Harper Torch.

Guzman, M. P. D. (2012). Barrier to Human Pappilomavirus Vaccination in selected University In Manila. Philippine: Women University Manila.

Hatta, M. (2009) Kanker serviks. Diunduh dari http://www.republika.co.id/berita/gayahidup/info-sehat/08/12/19/21144-meutiahatta-libatkan-pria-dalam-mencegah-kankerserviks pada 24 Februari 2014.

Hoque, E., \& hoque, M. (2009). Knowledge of and attitude towards cervical cancer among female university students in South Africa. South Africa: Mangosuthu University of Technology. Diunduh pada 12 Januari 2014.

Humaniz. (2010). Human Papiloma Virus (HPV), pentebab kanker serviks. Diunduh dari http://arumaniez21.wordpress. com/2010/02/21/hpv-penyebab-kankerserviks/ pada 16 Oktober 2013.

International Union Against Cancer (UICC).
(2009). International Congress Convention Association. Diunduh dari www.iccaworld. com pada 18 Oktober 2013.

Janice, M. A., \& Carolina, H. G. (2013). Health promotion in nursing (3rd ed). Thomson asian edition).

Julia, G. B. (2011). Nursing theories: The abse for professional nursing practice. Fullerton, CA: Departement of nursing California State University.

Kaplan-Myrth, N., \& Dollin, M., J. (2009). Cervical cancer awareness and HPV prevention in canada. Article PMCID: PMC1952601. The University of Ottawa. Diunduh pada November 2013.

Lalas, J. A. K. (2012). Relationshipof Job Performance Characteristics of Faculty Members In Selected Nursing School : Basis For An Action Plan. Philippine: Women University Manila.

Magdalen, M. M. (2013). Statistika penderita kanker di Indonesia. J Indon Med Assoc, 63(1), http://www.deherba.com/blog/ maureen-m.-magdalena.html pada Januari 2013.

Martha, L. E., F. S., \& Shirley,O. E. (2012). Oncology nursing (5th ed). St. Louis, Missouri: Mosby Elsevier.

Merriam-Webster's collegiate dictionary (15th ed.). (2009). Springfield, MA: MeriamWebster.

Michael, J. G. (2012). Multivitamins in the prevention of cancer in men the physicians' health study II randomized controlle trial. JAMA, 308(18), 1871-1880. doi:10.1001/ jama.2012.14641. Diunduh pada 15 Oktober 2013.

Michael, L. D. (2009). Encyclopedia of survey research methods. Diunduh dari http://srmo. sagepub.com/view/encyclopedia-of-surveyresearch-methods/n411.xml pada 25 Februari 2014.

Montgomery, K., Bloch, J. R., Bhattacharya 
Dedeh Sri Rahayu: Cervical Cancer Awareness: An Information Dissemination Campaign Indonesia

\& Montgomery, O. (2010). Human Papillomavirus and cervival cercer knowledge, health bealifs, and preventive practices in older women. Research Jognn, 39, 238-249; 2010. doi: 10.1111/j.15526909.2010.01136.x.

Nancy, P. J. ( 2009). Nutritisions essentials anf diet therapy. United States America: Saunders Elsevier.

Ndikom \& Ofi. (2012). Awareness, perception and factors affecting utilization of cervical cancer screening services among women in Ibadan, Nigeria. Reproductive-healthjournal. Diunduh dari Reproductive-healthjournal.com/content/9/1/11.

Pilliteri, A. (2010). Maternal and child health nursing: Care of the childbearing and childrearing family, ( $6^{\text {th }}$ ed.). Philadelphia: Lippincott William and Wilkins.

Polit, D. F. (2009). Nursing research generating and sssessing evidence for nursing practice. Philadelphia: Lippincott William and Wilkins.

Potter, P. A., \& Perry, A. G. (2013). Fundammental of nursing (8th ed). St Louis, Missouri: Elsevier Mosby.

Praptono, A. (2013). Biro pusat statistik Cimahi. Diunduh dari http://st2013.bps.go.id/ st2013esya.booklet/st3277.pdf pada 2013.

Provinsi database SIAK Jawa Barat. (2011). Profil Penduduk Jawa Barat pada tahun 2011. Diunduh dari http://www.jabarprov. go.id/index.php/subMenu/75 pada 17 Oktober 2013.

Ratih, O., Rahajeng, E., \& Kristanto, A. Y. (2011). Beberapa tumor dan kanker prevalensi. Jurnal. Departemen Kesehatan. Diunduh dari go. id/index. php/CPC/.../46 pada 27 Oktober, 2013.

Richard, C. W. (2011). Avoidable causes of cancer the role of green chemistry. Diunduh pada 16 Oktober 2013.

Robinson, F. (2010). Cervical cancer awareness varies. Practice Nurse 39(2), 9-10.

Sevilla, O., \& Punsalan, R. (2009). Reseach Methods. Book Store.

Sloan Network. (2013). Definition of gender. Diunduh dari http://workfamily.sas.upenn. edu/glossary/g/gender-definitions pada November 2013.

Sue, D. C., \& Patricia, L. K. (2008). Fundammental of nursing standards and practice,(3rd ed.). South Western:Thomson.

Susan, R. S. (2009). Essensial of maternity newborn, and women helth nursing. New York: Lippincot.

Susianto, I. A. (2009). Terjadinya kanker serviks. Diunduh dari http:// suaramerdeka.com/v1/index.php/read/ cetak/2009/10/22/84974/Terapi-LETzsebelum-Jadi-Kanker-Leher-Rahim.

The American Heritage, (2009). Dictionary of the English language, (4th ed.). United States America: Houghton Mifflin Company.

Toni, F. (2013). Definition dissemination of information. Diunduh dari http://referencesdefinitions.blurtit.com/35904/what-doesdissemination-of-information-mean-pada November 2013.

Ulber, S. (2012). Metode penelitian sosial. Bandung: Rafika Adita.

WebMD, LLC., (2013). The cervix. Diunduh dari http://women.webmd.com/picture-ofthe-cervix?page=3 pada November 2013.

Xu caiyan, Zhang, W., Wu, M., \& Zhang, S. (2011). Knowledge of cervical cancer among 25-54-year-old women in Beijing. doi 10.1007/s13187-011-0228-9. Diunduh pada 16 Oktober 2013. 